Open Access at : http://jurnal.umt.ac.id/index.php/replik/index

\title{
PEMILIHAN KEPALA DAERAH DI INDONESIA: (Studi Pemungutan Suara Ulang dalam Putusan Nomor. 120/PHP.BUP-XIV/2016)
}

\author{
Ahmad \\ Fakultas Hukum Universitas Muhammadiyah Tangerang \\ E-mail : ahmad@umt.ac.id
}

\begin{abstract}
Abstrak
Pemilihan kepala daerah di Indonesia secara langsung diselenggarakan oleh Komisi Pemilihan Umum dan Bawaslu serta Dewan Kehormatan Penyelenggara Pemilu (DKPP) yang bertugas menegakkan kode etik bagi penyelenggara pemilu dan penyelesaian perselisihan hasil diselesaikan oleh Mahkamah Konstitusi. Dalam penyelenggaraan pemilihan terdapat alasan untuk dapat dilakukan pemungutan suara ulang. Adapun permasalahan penelitian yakni apakah alasan Pemungutan Suara Ulang dalam Putusan No. 120/PHP.BUP-XIV/2016 dan bagaimana mekanisme pelaksanaan Pemungutan Suara Ulang di TPS dan Pasca Putusan Mahkamah Konstitusi. Metode penelitian yang digunakan adalah penelitian normative dengan menggunakan deskriptif analitis. Adapun hasil penelitian yakni alasan pemungutan suara ulang yaitu; ganguan keamanan, pembukaan kotak suara, pemilih memberi tanda khusus pada surat suara, Petugas KPPS merusak lebih dari I (satu) surat suara, adanya lebih dari 1 (satu) orang yang menggunakan hak pilih lebih dari sekali dan adanya lebih dari 1 (satu) pemilih yang tidak terdaftar menggunakan hak pilih. Alasan tersebut yang telah dibuktikan melalui proses pemeriksaan yang dilakukan oleh Pengawas dimasing-masing jenjang yang kemudian dikeluarkan rekomendasi untuk dilakukan Pemungutan suara Ulang sedangkan mekanisme Pemungutan suara Ulang dilakukan oleh KPUD dan Panwasluh dengan supervisi dan kordinasi dilakukan oleh lembaga penyelenggara pada tingkat di atasnya. Atas hasil penelitian sebagaimana yang dijelaskan di atas, penulis merekomendasikan alasan pelaksanaan pemungutan suara ulang hanya dapat dilakukan sebelum adanya putusan MK bukan pasca putusan MK sehingga kemurnian suara pemilih tetap terjaga keasliaannya dan menghindari adanya trasaksi suara di TPS yang di PSUkan.
\end{abstract}

Kata Kunci : Pilkada Serentak, Pemungutan Suara Ulang, Pengawas dan Penyelenggara, Putusan Mahkamah Konstitusi. 


\section{PENDAHULUAN}

Ketentuan dasar mengenai pengisian jabatan kepala daerah (Gubernur, Bupati dan atau Walikota) telah dirumuskan dalam Pasal 18 ayat (4) UUD 1945 itu berbunyi: "Gubernur, Bupati, dan Walikota masing-masing sebagai Kepala Pemerintah Daerah Provinsi, Kabupaten, dan Kota dipilih secara demokratis". Makna demokratis diwujudkan dalam dua bentuk yakni demokrasi langsung dan demokrasi tidak langsung, dalam konteks pemilihan kepada daerah di Indonesia,pernah menerapkan pemilihan kepada daerah secara tidak langsung yakni pemilihan melalui Dewan Perwakilan Daerah (DPRD) dan pemilihan kepala daerah secara langsung telah dilakukan sejak tahun 2005 kecuali pemilihan gubernur dan Wakil Gubernur Daerah Istimewa Yogyakarta.

Untuk menjamin pemilihan Gubernur, Bupati, dan Walikota dilaksanakan secara demokratis sebagaimana diamanatkan dalam Pasal 18 ayat (4) Undang-Undang Dasar Negara Republik Indonesia Tahun 1945 maka kedaulatan rakyat serta demokrasi dari rakyat, oleh rakyat, dan untuk rakyat wajib dihormati sebagai syarat utama pelaksanaan pemilihan Gubernur, Bupati, dan Walikota. kedaulatan rakyat dan demokrasi, perlu ditegaskan dengan pelaksanaan pemilihan Gubernur, Bupati, dan Walikota secara langsung oleh rakyat, dengan tetap melakukan beberapa perbaikan mendasar atas berbagai permasalahan pemilihan langsung yang selama ini telah dijalankan.

Implementasi pemilihan kepala daerah langsung (Pilkada), pertama kali diatur dalam Undang-Undang Nomor 32 ahun 2004 tentang Pemerintahan Daerah. Istilah pilkada mengalami perubahan menjadi pemilukada setelahnya adanya putusan MK yang memasukan menjadi bagian pemilu dan pengaturan pengalihan wewenang mengadili hasil sengketa pilkada dari MA ke MK. ${ }^{1}$ Semangat pilkada langsung merupakan langkah koreksi terhadap mekanisme pemilihan melalui DPRD ${ }^{2}$. Pilkada langsung mendekati makna demokrasi ${ }^{3}$. Pilkada langsung pertama kali

1 Heru Widodo, "Penyelesaian Sengketa Hasil Pemilukada: Evaluasi terhadap Prosedur Beracara di Mahkamah Konstitusi Indonesia Tahun 2008-2014, Disertasi Program Doktor Ilmu Hukum Universitas Pedjadjaran Bandung, 2017, hlm. 1

2 Suharizal, Pemilukada: Regulasi, Dinamika dan Konsep Mendatang, Jakarta: Raja Grafindo, 2011, hlm. 23

3 Mahfud MD, "Evaluasi Pemilukada dalam Prespektif Demokrasi dan Hukum”, dalam 
diselenggarakan tanggal 1 Juni 2005 di Kabupaten Kutai Kartanegara Kalimantan Timur, sedangkan pemilihan terakhir yang menggunakan UU No 32/2004 Provinsi Lampung tanggal 9 April 2014.

Dinamika penyelengaraan pemilihan umum dan pemilihan kepada daerah di Indonesia telah memberikan perlindungan atas hak pilih setiap warga negara untuk menggunakan hak pilihnya secara langsung baik yang terdaftar dalam Daftar Pemilih Tetap (DPT) dan atau hanya dengan menggunakan Kartu Tanda Penduduk (KTP) atau Surat Keterangan. Hal ini ditegaskan sesuai putusan Mahkamah Konstitusi dalam Perkara No. 102/PUU-VII/2009 terkait pengujian Pasal 28 dan Pasal 111 UU No 42 Tahun 2008 tentang Pemilihan Presiden dan Wakil Presiden. Demikian juga halnya dengan Putusan No. 28/PHPU.D-VIII/2010 tentang Perselisihan Hasil Pemilukada Gresik. Dalam putusan ini, MK menyatakan pemilih yang belum terdaftar dalam DPT dapat menggunakan haknya dengan menunjukan KTP atau paspor.

Demikian juga halnya dengan Putusan No 209-210/PHPU.D-VIII/2010 tentang Perselisihan Hasil Pemilukada Tangerang Selatan dan Putusan No 77/PHPU.D-VIII/2012 tentang Perselisihan Hasil Pemilukada Brebes," dalam rangka menjamin hak konstitusional warga untuk memilih khususnya pemilukada baik yang terdaftar dalam DPT atau tidak terdaftar tetapi memiliki KTP asli yang berlaku. MK merasa perlu memerintahkan KPU untuk membuat aturan khusus terkait hal tersebut. Sehingga dengan peritah putusan MK tersebut KPU telah membuat peraturan yang dapat memberikan kepastian hukum bagi pemilih agar tetap dapat menggunakan hak pilihnya meskipun hanya mempunyai KTP.

Kemudian dalam Perkembangannya melalui Pasal 201 ayat (1) UndangUndang Nomor 1 Tahun 2015 tentang Penetapan Peraturan Pemerintah Pengganti Undang-Undang No. 1 Tahun 2014 tentang Pemilihan Gubernur, Bupati dan Walikota menjadi Undang-Undang dan terakhir telah diubah dengan Undang-Undang No. 10 Tahun 2016. Lebih lanjut pemilihan kepala daerah secara serentah telah ditetapkan sebagai berikut; 1). para kepala daerah yang masa jabatannya berakhir pada tahun 2015 dan Januari sampai dengan bulan Juni 2016, Pilkada Serentak pertama dilaksanakan bulan Desember 2015 dengan rincian Sembilan Provinsi memilih 
Gubernur dan 260 Kabupaten/Kota memilih Bupati/Walikota; 2). para kepala daerah yang masa jabatannya berakhir pada Juli sampai dengan Desember 2016 dan tahun 2017 maka Pilkada Serentak II dilaksanakan bulan Februari 2017 dengan jumlah 101 Daerah; 3). para kepala daerah yang masa jabatannya berakhir pada Tahun 2018 dan Tahun 2019, Pilkada serentak dilaksanakan pada tanggal 27 Juni 2018 dengan jumlah 171 daerah; 4).Pilkada Serentak berikutnya Tahun 2020, Tahun 2022 dan Tahun 2023; 5). Pilkada serentak nasional akan dilaksanakan Tahun $2027{ }^{4}$

Menurut ketentuan Pasal 1 angka 1 Undang-undang Nomor 8 Tahun 2015 tentang Perubahan Atas Undang-Undang Nomor 1 Tahun 2015 Tentang Penetapan Peraturan Pemerintah Pengganti Undang-Undang Nomor 1 Tahun 2014 Tentang Pemilihan Gubernur, Bupati, Dan Walikota Menjadi Undang-Undang menentukan "Pemilihan Gubernur dan Wakil Gubernur, Bupati dan Wakil Bupati, serta Walikota dan Wakil Walikota yang selanjutnya disebut Pemilihan adalah pelaksanaan kedaulatan rakyat di wilayah provinsi dan kabupaten/kota untuk memilih Gubernur dan Wakil Gubernur, Bupati dan Wakil Bupati, serta Walikota dan Wakil Walikota secara langsung dan demokratis.

Penyelenggaraan pemilihan dilaksanakan oleh komisi independen dan mandiri sebagaimana ketentuan Pasal 1 angka 7 UU Pilkada mengatur bahwa Komisi Pemilihan Umum (KPU) adalah lembaga penyelenggara pemilihan umum sebagaimana dimaksud dalam undang-undang yang mengatur mengenai penyelenggara pemilihan umum yang diberikan tugas dan wewenang dalam penyelenggaraan Pemilihan berdasarkan ketentuan yang diatur dalam UndangUndang ini. Adapun pada tingkat Provinsi dan Kabupaten/kota, tugas dan wewenang dalam penyelenggaraan pemilihan dilaksanakan oleh KPUD Provinsi dan KPUD Kabupaten/Kota (Pasal 1 angka 8 dan angka 9 UU Pilkada). Sedangkan penyelenggara ditingkat kecamatan dilaksanakan oleh Panitian Pemilihan Kecamatan (PPK), penyelenggara ditingkat desa oleh Panitia Pemungutan Suara (PPS),

4 Janedjri M. Gaffar, Materi Bimtek "Sosialisasi Pemahaman Hak Konstitusional Warga Negara bagi Asosiasi Dosen Pendidikan Pancasila dan Kewarganegaraan, dan Asosiasi Pengajar Hukum Acara Mahkamah Konstitusi DKI Jakarta”, Jakarta, 12 November 2015. 
Penyelenggara ditingkat Tempat Pemungutan Suara oleh Kelompok Penyelenggara Pemungutan Suara (KPPS).

Fungsi pengawasan dilaksanakan secara terstruktur sebagaimana ketentuan Pasal 1 angka 10 UU Pilkada mengatur Badan Pengawas Pemilihan Umum (Bawaslu) adalah lembaga penyelenggara pemilihan umum yang bertugas mengawasi penyelenggaraan pemilihan umum di seluruh wilayah Negara Kesatuan Republik Indonesia sebagaimana dimaksud dalam undang-undang yang mengatur mengenai penyelenggara pemilihan umum yang diberikan tugas dan wewenang dalam pengawasan penyelenggaraan Pemilihan berdasarkan ketentuan yang diatur dalam Undang-Undang ini. Adapun pada tingkat Provinsi dan Kabupaten/kota, tugas dan wewenang dalam pengawasan penyelenggaraan pemilihan dilaksanakan oleh Bawaslu Provinsi dan Panwas Kabupaten/Kota (Pasal 1 angka 16 dan angka 17 UU Pilkada). Sedangkan Pengawasan penyelenggara pemilihan ditingkat kecamatan dilaksanakan oleh Panwas Kecamatan, dan pengawas pemilihan lapangan (PPL) ditingkat desa/kelurahan oleh (PPL), pengawas ditingkat Tempat Pemungutan Suara oleh Pengawas TPS.

Untuk menangani pelanggaran kode etik maka ketentuan UU Pilkada menentukan Dewan Kehormatan Penyelenggara Pemilihan Umum (DKPP) sebagai lembaga yang bertugas menangani pelanggaran kode etik penyelenggara pemilihan umum dan merupakan satu kesatuan fungsi penyelenggaraan pemilihan umum sebagaimana dimaksud dalam undang-undang yang mengatur mengenai penyelenggara pemilihan umum yang diberikan tugas dan wewenang dalam menangani pelanggaran kode etik penyelenggara Pemilihan berdasarkan ketentuan yang diatur dalam Undang-Undang ini.

Pemungutan Suara merupakan proses pemberian suara olehPemilih di TPS dengan cara mencoblos pada nomor urut,nama, atau foto Pasangan Calon. (Pasal 1 angka 22 PKPU No.8/2018) sedangkan Penghitungan Suara merupakan proses penghitungan Surat Suara oleh KPPS untuk menentukan suara sah yang diperoleh Pasangan Calon, Surat Suara yang dinyatakan tidak sah, Surat Suara yang tidak digunakan dan Surat Suara rusak/keliru dicoblos. (Pasal 1 angka 23 PKPU No. 8/2018). 
Bahwa dalam putusan Mahkamah Konstitusi No. 120/PHP.BUP-XIV/2016 yang mengadili dan memutus penyelesaian sengketa hasil pemilihan kepala daerah Kabupaten Muna Provinsi Sulawesi Tenggara tahun 2015 ditemukan fakta yang terungkap dipersidangan Mahkamah Konstitusi yakni terdapat lebih dari 1 (satu) orang pemilih yang menggunakan hak pilihnya lebih dari satu kali di TPS yang berbeda. Atas dasar itu Mahkamah Konstitusi menjatuhkan putusan untuk memerintahkan untuk dilakukan pemungutan suara ulang di TPS-TPS yang dimaksud.

Berdasarkan uraian sebagaimana yang dijelaskan di atas, maka penulis menganggap perlu untuk melakukan penelitian dan analisis atas alasan-alasan untuk dapat dilakukan pemungutan suara ulang oleah Bawaslu dan alasan-alasan hukum dilakukan pemungutan suara ulang pasca putusan Mahkamah Konstitusi.

\section{METODE PENELITIAN}

Jenis penelitian ini adalah penelitian pustaka yang sumber datanya diperoleh melalui penelitian terhadap berbagai literatur yang relevan dengan obyek penelitian dan Putusan No. 120/PHP.BUP-XIV/2016. Sebagai sebuah penelitian yang menelusuri prinsip dan konsep hukum mengenai alasan Pemungutan Suara Ulang, maka secara metodologis penelitian ini akan mengkaji konsep-konsep Pemungutan suara ulang dan implementasinya di Mahkamah Konstitusi. Hal ini penting dilakukan karena hanya dari konsep hukum tersebut ditemukan makna atas norma-norma hukum tersebut dalam kontek praktiknya.

Adapun tipe penelitian ini adalah deskriptif analitis kualitatif, artinya penelitian dilakukan dengan mendeskripsikan, menganalisis secara kualitatif atas data yang berkaitan dengan obyek penelitian baik dalam hukum positif maupun putusan Mahkamah Konstitusi untuk menarik kesimpulan sesuai dengan pokok masalahnya.

\section{PEMBAHASAN}

\section{A. Alasan Pemungutan Suara Ulang Pasca Putusan Mahkamah Konstitusi}

Ketentuan pemilihan kepala daerah untuk dapat dilakukan Pemungutan Suara Ulang (PSU) telah diatur dalam Pasal 112 UU Pilkada sebagi berikut; 
1. Pemungutan suara di TPS dapat diulang jika terjadi gangguan keamanan yang mengakibatkan hasil pemungutan suara tidak dapat digunakan atau penghitungan suara tidak dapat dilakukan.

2. Pemungutan suara di TPS dapat diulang jika dari hasil penelitian dan pemeriksaan Panwas Kecamatan terbukti terdapat 1 (satu) atau lebih keadaan sebagai berikut:

a. pembukaan kotak suara dan/atau berkas pemungutan dan penghitungan suara tidak dilakukan menurut tata cara yang ditetapkan dalam peraturan perundangundangan;

b. petugas KPPS meminta Pemilih memberi tanda khusus, menandatangani, atau menulis nama atau alamatnya pada surat suara yang sudah digunakan;

c. petugas KPPS merusak lebih dari satu surat suara yang sudah digunakan oleh Pemilih sehingga surat suara tersebut menjadi tidak sah;

d. lebih dari seorang Pemilih menggunakan hak pilih lebih dari satu kali, pada TPS yang sama atau TPS yang berbeda; dan/atau

e. lebih dari seorang Pemilih yang tidak terdaftar sebagai Pemilih, mendapat kesempatan memberikan suara pada TPS.

Demikian juga halnya dengan Peraturan Komisi Pemilihan Umum Nomor 8 Tahun 2018 Tentang Pemungutan Dan Penghitungan Suara Pemilihan Gubernur Dan Wakil Gubernur, Bupati Dan Wakil Bupati, Dan/Atau Walikota Dan Wakil Walikota (PKPU No. 8/2018), mengatur Pemungutan suara ulang (PSU) di Tempat Pemungutan Suara (TPS) dapat dilakukan sebagaimana ketentuan Pasal 59 PKPU No 8/2018 dengan alasan-alasan sebagai berikut;

1. Pemungutan Suara di TPS dapat diulang apabila terjadi gangguan keamanan yang mengakibatkan hasil Pemungutan Suara tidak dapat digunakan atau Penghitungan Suara tidak dapat dilakukan.

2. Pemungutan Suara di TPS dapat diulang apabila dari hasil penelitian dan pemeriksaan Panwas Kecamatan terbukti terdapat 1 (satu) atau lebih keadaan sebagaiberikut: 
a. pembukaan kotak suara dan/atau berkas Pemungutan dan Penghitungan Suara tidak dilakukan menurut tata cara yang ditetapkan dalam peraturan perundang-undangan;

b. petugas KPPS meminta Pemilih memberi tanda khusus, menandatangani, atau menulis nama atau alamatnya pada Surat Suara yang sudah digunakan;

c. petugas KPPS merusak lebih dari 1 (satu) Surat Suara yang sudah digunakan oleh Pemilih sehingga Surat Suara tersebut menjadi tidak sah;

d. $\quad$ lebih dari 1 (satu) orang Pemilih menggunakan hakpilih lebih dari 1 (satu) kali pada TPS yang samaatau TPS yang berbeda; dan/atau

e. $\quad$ lebih dari 1 (satu) orang Pemilih yang tidak terdaftarsebagai Pemilih mendapat kesempatanmemberikansuara pada TPS.

Berdasarkan ketentuan di atas maka pemungutan suara ulang dapat dilakukan dengan alasan apabila terjadi gangguan keamanan yang mengakibatkan hasil Pemungutan Suara tidak dapat digunakan atau Penghitungan Suara tidak dapat dilakukan. Pemungutan suara ulang juga dapat dilakukan dengan alasan apabila dari hasil penelitian dan pemeriksaan Panwas Kecamatan terbukti terdapat 1 (satu) atau lebih keadaan yakni; 1) pembukaan kotak suara yang dilakukan tidak sesuai denga cara yang telah ditetapkan oleh peraturan perundang-undangan; 2) petugas KPPS meminta Pemilih memberi tanda khusus, menandatangani, atau menulis nama atau alamatnya pada surat suara yang sudah digunakan; 3) petugas KPPS merusak lebih dari 1 (satu) Surat Suara yang sudah digunakan oleh Pemilih; 4) lebih dari 1 (satu) orang Pemilih menggunakan hak pilih lebih dari 1 (satu) kali pada TPS yang sama atau TPS yang berbeda dan lebih dari 1 (satu) orang Pemilih yang tidak terdaftar sebagai Pemilih mendapat kesempatan memberikan suara pada TPS.

Pemilihan Kepala Daerah Kabupaten Muna dilaksanakan bersama dengan pelaksanaan pemilihan kepada daerah serentah pertama tahun 2015 yakni 9 Desember 2015. Untuk diketahui, kandidat Pilkada Kabupaten Muna terdiri dari 3 (tiga) 
Pasangan calon yakni nomor urut 1 Rusman Emba-Malik Ditu (Rumah Kita), nomor urut 2. Arwaha-Samuna dan nomor urut 3 Baharuddin-La Pili (Dokter Pilihanku) ${ }^{5}$.

Adapun hasil pemilihan kepala daerah Kabupaten Muna diikuti oleh 3 (tiga) pasangan calon dan hasil pemilihan tersebut masing-masing Pasangan calon berdasarkan Penetapan hasil perhitungan suara oleh KPUD, perolehan suara masingmasing pasangan calon, adalah sebagai berikut:

\begin{tabular}{|l|l|l|}
\hline No. & \multicolumn{1}{|c|}{ Nama Pasangan Calon } & Perolehan Suara \\
\hline 1. & Pasangan Nomor Urut 1 ( Pemohon ) & 47.434 \\
\hline 2. & Pasangan Nomor Urut 2 & 5.408 \\
\hline 3. & Pasangan Nomor Urut 3 & 47.467 \\
\hline & Jumlah Suara & 100.309 \\
\hline
\end{tabular}

(Berdasarkan tabel diatas Pemohon berada di peringkat kedua dengan perolehan suara sebanyak 47.434 suara). Selisih suara antara pemenang dengan yang kalah hanya 33 suara.

Hasil pemilihan kepala daerah Kabupaten Muna tidak dapat diterima oleh Pasangan calon No. 1 karena KPUD sebagai pelakasana telah bertindak lalai sehingga hasil rekapitulasi yang telah ditetapkan oleh KPU harus dibatalkan melalui permohonan sengketa perselisihan hasil pemilihan di Mahkamah Konstitusi. Perkara Perselisihan Hasil Pemilihan Kepala Daerah Kabupaten Muna Provinsi Sulawesi Tenggara diajukan sengketa kepada Mahkamah Konstitusi sebagaimana permohonan dengan surat permohonannya bertanggal 21 Desember 2015 yang diterima di Kepaniteraan Mahkamah Konstitusi pada tanggal 21 Desember 2015 berdasarkan Akta Pengajuan Permohonan Pemohon Nomor 115/PAN.MK/2015 dan dicatat dalam Buku Registrasi Perkara Konstitusi dengan Perkara Nomor 120/PHP.BUP-XIV/2016 tanggal 4 Januari 2016 yang telah diperbaiki dan diterima di Kepaniteraan Mahkamah pada tanggal 3 Januari 2016, 15 Januari 2016, 29 Januari 2016, 4 Februari 2016, dan 5 Februari 2016.

5 http://bawaslu.go.id/id/berita/psu-jilid-ii-pilkada-kabupaten-muna-digelar, diakses tanggal 10 Agustus 2018. 
Pasangan Calon yang Kalah (Pemohon) dalam perkara sengketa perselisihan hasil pemilihan Bupati dan Wakil Bupati di Kabupaten Muna Sulawesi Tenggara mendalilkan terdapat lebih dari seorang pemilih yang melakukan pencoblosan ganda, yang terjadi di TPS 2 Desa Oempu Kecamatan Tongkuno, TPS 2 Desa Lianosa Kecamatan Tongkuno Selatan, TPS 1 Desa Matarawa Kecamatan Watopute, TPS 2 dan TPS 3 Desa Lohia Kecamatan Lohia, TPS 1 Desa Koholifano Kecamatan Pasir Putih, TPS 4 Kelurahan Raha I dan TPS 4 Kelurahan Wamponiki, sehingga terhadap pelanggaran tersebut harus diadakan Pemungutan Suara Ulang (PSU). Untuk menguatkan dalil tersebut, Pemohon mengajukan bukti surat/tulisan yang membuktikan adanya dokumen yang dapat menjelaskan adanya lebih daru satu pemilih yang menggunakan hak pilih lebih dari satu kali serta keterangan saksi yang menjelaskan hal yang dimaksud.

Terhadap dalil Pemohon tersebut, KPU Kabupaten Muna (Termohon) membantah dengan menyatakan pada pokoknya Termohon telah melakukan langkahlangkah untuk mengantisipasi adanya pemilih yang akan melakukan pencoblosan lebih dari satu kali, antara lain, dengan membuat pengumuman atau himbauan kepada seluruh masyarakat Kabupaten Muna yang sudah memenuhi syarat sebagai pemilih untuk melaksanakan hak pilihnya hanya satu kali pencoblosan; Termohon telah melakukan bimbingan teknis kepada PPK, PPS dan KPPS tentang Tata Cara Pemungutan dan Penghitungan Suara di TPS; dan Termohon telah melakukan sosialisasi ke sekolah-sekolah dan perguruan tinggi di Kabupaten Muna. Termohon juga telah memberikan materi pembekalan terhadap saksi pasangan calon Pemohon dimana salah satu materinya adalah mengajak pasangan calon dan para saksi pasangan calon di seluruh TPS di Wilayah Kabupaten Muna untuk bersama-sama penyelenggara, mengawasi dan mencegah adanya pelanggaran- pelanggaran yang berpotensi terjadi dalam proses pemilihan. Untuk menguatkan bantahannya, Termohon mengajukan bukti surat/tulisan yang membuktikan hal yang sebaliknya dengan dalil pemohon serta keterangan saksi ditempat pemunguntan suara yang didalilkan oleh Pemohon.

Pasangan Calon Pemenang (Pihak Terkait) memberikan keterangan pada pokoknya membantah dalil permohonan Pemohon a quo. Tidak benar terdapat 
pemilih ganda di TPS 2 Desa Oempu Kecamatan Tongkuno, TPS 2 Desa Lianosa Kecamatan Tongkuno Selatan, TPS 1 Desa Matarawa Kecamatan Watopute, TPS 2 dan TPS 3 Desa Lohia Kecamatan Lohia, TPS 1 Desa Koholifano Kecamatan Pasir Putih, TPS 1 Desa Marobo Kecamatan Marobo, TPS 4 Kelurahan Raha I dan TPS 4 Kelurahan Wamponiki Kecamatan Katobu. Untuk menguatkan keterangannya, Pihak Terkait mengajukan bukti surat/tulisan yang membuktikan bahwa tidak ada pemilih yang menggunakan hak pilih lebih daru satu kali dan diperkuat keterangan saksi fakta yang menerangkat tidak ada kejadian sebagaiama yang dimaksud Pemohon serta keterangan ahli untuk menjelaskan dalil bantahannya.

Di dalam persidangan, atas permintaan Mahkamah, telah didengar keterangan Panwas Kabupaten Muna yang kehadirannya telah disetujui oleh Bawaslu dan memberikan keterangan yang pada pokoknya menyatakan bahwa dalam klarifikasi Drs. Hamka Hakim dan isterinya, yaitu Marlina D, mengakui telah melakukan pencoblosan di dua TPS yang berbeda yakni pada TPS 4 Kelurahan Raha I dan TPS 4 Kelurahan Wamponiki Kecamatan Katobu. Panwas Kabupaten Muna kemudian merekomendasikan kepada KPU Kabupaten Muna untuk melakukan Pemungutan Suara Ulang di TPS 4 Kelurahan Raha I dan TPS 4 Kelurahan Wamponiki, namun rekomendasi Panwas Kabupaten Muna tidak ditindaklanjuti oleh KPU dengan alasan bahwa telah melewati batas waktu pelaksanaan Pemungutan Suara Ulang.

Terhadap dalil Pemohon a quo, Mahkamah memberikan pertimbangkan sebagai berikut:

1. Berdasarkan fakta persidangan, dari keterangan saksi Pemohon La Ode Amrin memang benar terdapat pencoblosan ganda yang dilakukan oleh Drs. Hamka Hakim dan isterinya yang bernama Marlina D yaitu di TPS 4 Kelurahan Raha I dan kemudian berpindah memilih di TPS 4 Kelurahan Wamponiki;

2. Berdasarkan keterangan Panwas Kabupaten Muna para terlapor (Drs. Hamka Hakim dan Marlina D) mengakui telah melakukan pencoblosan di dua TPS yang berbeda yakni TPS 4 Kelurahan Raha I dan TPS 4 Kelurahan Wamponiki Kecamatan Katobu. Di samping itu, dalam klarifikasi terhadap Ketua KPPS TPS 4 Kelurahan Raha I atas nama Muh. Zulkifli, dan Ketua KPPS TPS 4 Kelurahan Wamponiki atas nama Hasrin, keduanya mengakui dan 
membenarkan adanya warga atas nama Drs. Hamka Hakim dan Marlina D mencoblos dua kali;

3. Terhadap fakta adanya lebih dari 1 (satu) pemilih menggunakan hak pilih sebanya dua kali, Termohon dan Pihak Terkait tidak membantahnya;

4. Menurut ketentuan Pasal 112 ayat (2) huruf d Undang-Undang Nomor 1 Tahun 2015 sebagaimana telah diubah dengan Undang-Undang Nomor 8 Tahun 2015 menyatakan bahwa:

“(2) Pemungutan suara di TPS dapat diulang jika dari hasil penelitian dan pemeriksaan Panwas Kecamatan terbukti terdapat 1 (satu) atau lebih keadaan sebagai berikut:

a. lebih dari seorang Pemilih menggunakan hak pilih lebih dari satu kali, pada TPS yang sama atau TPS yang berbeda; dan/atau

Berdasarkan fakta dan ketentuan hukum di atas, menurut Mahkamah, telah terbukti secara sah dan meyakinkan terjadi penggunaan hak pilih lebih dari satu kali yang dilakukan oleh Drs. Hamka Hakim dan Marlina D, sebagaimana dimaksud dalam Pasal 112 ayat (2) huruf d a quo, yaitu di TPS 4 Kelurahan Raha I dan TPS 4 Kelurahan Wamponiki Kecamatan Katobu, sehingga menjadi beralasan untuk dilakukan Pemungutan Suara Ulang (PSU) karena dalam pemeriksaan persidangan tidak ditemukan bukti kedua pemilih tersebut terdaftar sebagai pemilih yang sah di salah satu dari dua TPS tersebut. Oleh karenanya, menurut Mahkamah, dalil Pemohon a quo sepanjang mengenai penggunaan hak pilih lebih dari satu kali di TPS 4 Kelurahan Raha I dan TPS 4 Kelurahan Wamponiki Kecamatan Katobu beralasan menurut hukum

Pemohon mendalilkan adanya penerbitan Surat Keterangan Tempat Tinggal (SKTT) 2 (dua) hari menjelang pemungutan suara Pemilihan Bupati dan Wakil Bupati Kabupaten Muna Tahun 2015 yang cukup masif dilakukan oleh Kepala Desa/Lurah/Camat setempat. untuk menguatkan dalil a quo, Pemohon mengajukan bukti surat/tulisan yang membuktikan dalilnya serta keterangan saksi-saksi yang dapat menjelaskan kebenran dalil pemohon.

Terhadap dalil Pemohon tersebut, Termohon membantah yang pada pokoknya Pemohon mendalilkan ada 18 SKTT yang diterbitkan untuk warga Desa Waburense 
Kabupaten Buton Tengah. Tetapi pada kenyataannya Pemohon hanya bisa membuktikan tujuh orang saja yang mengaku menggunakan SKTT tersebut dan tidak bisa dipastikan juga suara tersebut untuk Pasangan Calon Nomor 3. Bahwa penyelenggara tidak mempunyai kewenangan melarang pemilih yang menggunakan SKTT yang diterbitkan oleh Instansi Terkait. Untuk menguatkan bantahannya, Termohon mengajukan bukti surat/tulisan untuk membantah dalil Pemohon.

Terhadap dalil Pemohon a quo, Pihak Terkait memberikan keterangan yang pada pokoknya menyatakan tidak benar terdapat banyak Kepala Desa atau sebutan lainnya di seluruh Kabupaten Muna yang menerbitkan SKTT secara masif. Terbukti dalam permohonannya, Pemohon hanya mampu menunjukkan penerbitan SKTT $a$ quo di satu desa saja, yaitu Desa Marobo namun Pihak terkait tidak mengajukan bukti untuk memperkuat dalil-dalil keterangannya.

Panwas Kabupaten Muna pada pokoknya menerangkan pengguna SKTT tersebut adalah warga Desa Waburense, Kecamatan Mawasangka, Kabupaten Buton Tengah, sehingga Panwas Kabupaten Muna menyimpulkan Kepala Desa Marobo, Camat Marobo, dan Ketua KPPS TPS 1 Marobo diduga melanggar Pasal $181 \mathrm{UU}$ 1/2015 sebagaimana telah diubah dengan UU 8/2015. Kasus ini telah ditindaklanjuti oleh Kepolisian, Kejaksaan dan telah diputus oleh Pengadilan Negeri Raha dengan amar putusan yang pada pokoknya menyatakan terdakwa (Kepala Desa Marobo) terbukti melakukan perbuatan mengeluarkan SKTT, tetapi bukan sebagai perbuatan yang melanggar aturan sesuai dengan unsur pasal yang disangkakan kepada terdakwa. Atas terbitnya putusan tersebut, Jaksa Penuntut Umum melakukan upaya hukum banding ke Pengadilan Tinggi Sulawesi Tenggara.

Mahkamah mempertimbangkan sebagai berikut:

1. Bahwa Saksi Munir menerangkan yang bersangkutan mengakui menerima 16 lembar SKTT dari Kepala Desa Marobo yang bernama La Ode Bou untuk dibagikan kepada warga Desa Waburense, Kecamatan Mawasangka, Kabupaten Buton Tengah;

2. Bahwa Saksi Boy selaku salah satu warga Desa Waburense, Kecamatan Mawasangka, Kabupaten Buton Tengah, yang menerima SKTT dari Saksi 
Munir (mertuanya) tersebut, menggunakan SKTT tersebut untuk memilih di TPS 1 Desa Marobo. Saksi juga melihat ada 4 (empat) orang warga Desa Waburense, Kecamatan Mawasangka, Kabupaten Buton Tengah yang juga memilih di TPS 1 Desa Marobo dengan menggunakan SKTT tersebut;

3. Bahwa Pasal 112 ayat (2) huruf e Undang-Undang Nomor 1 Tahun 2015 sebagaimana telah diubah dengan Undang-Undang Nomor 8 Tahun 2015 menyatakan bahwa:

“(2) Pemungutan suara di TPS dapat diulang jika dari hasil penelitian dan pemeriksaan Panwas Kecamatan terbukti terdapat 1 (satu) atau lebih keadaan sebagai berikut:

\section{a. lebih dari seorang Pemilih yang tidak terdaftar sebagai Pemilih, mendapat kesempatan memberikan suara pada TPS.}

4. Berdasarkan fakta dan ketentuan hukum di atas, menurut Mahkamah, telah terbukti terjadi pemilih yang tidak terdaftar sebagai pemilih memilih di Kabupaten Muna karena yang bersangkutan adalah penduduk Kabupaten Buton Tengah, sehingga hal tersebut secara sah dan meyakinkan terbukti melanggar ketentuan Pasal 112 ayat (2) huruf e UU 1/2015 sebagaimana telah diubah dengan UU 8/2015, sehingga menjadi beralasan untuk dilakukan Pemungutan Suara Ulang. Oleh karenanya, menurut Mahkamah, dalil Pemohon a quo sepanjang mengenai Pemungutan Suara Ulang (PSU) di TPS 1 Desa Marobo beralasan menurut hukum terjadi pelanggaran dalam penyelenggaraan Pemilihan Bupati dan Wakil Bupati Kabupaten Muna Tahun 2015 di 3 (tiga) TPS, yaitu TPS 4 Kelurahan Raha I dan TPS 4 Kelurahan Wamponiki, Kecamatan Katobu, serta TPS 1 Desa Marobo, Kecamatan Marobo, Kabupaten Muna.

Dalam amar Putusan Mahkamah Konstitusi membatalkan Keputusan Komisi Pemilihan Umum Kabupaten Muna Nomor 73/Kpts/KPU-Kab.026.433541/2015 tentang Penetapan Rekapitulasi Hasil Penghitungan Perolehan Suara dan Hasil Pemilihan Bupati dan Wakil Bupati Kabupaten Muna Tahun 2015, tanggal 19 Desember 2015, sepanjang mengenai perolehan suara masing-masing pasangan calon di 3 (tiga) TPS yaitu TPS 4 Kelurahan Raha I dan TPS 4 Kelurahan 
Wamponiki, Kecamatan Katobu, serta TPS 1 Desa Marobo, Kecamatan Marobo, Kabupaten Muna.

Akan tetapi hasil pelaksanaan PSU tersebut masih ditemukan adanya pelanggaran hukum sehingga Mahkamah Konstitusi memerintahkan kepada penyelenggara KPUD dan Panwaslu Kabupaten Muna untuk dmelaksanakan PSU jilid II di dua TPS yakni di TPS 4 Kelurahan Raha I dan TPS 4 Kelurahan Wamponiki, Kecamatan Katobu yang digelar pada hari Minggu 19 Juni 2016. Meskipun pada akhirnya Pasangan calon yang semula menang dengan selisih 33 (tiga puluh tiga) suara dan kemudian setelah dilakukan PSU jilid II, lalu digabungkan dengan hasil perolehan suara dilau dari yang di PSUkan dan hasil akhirnya dimenangkan oleh Pasangan calon yang mengajukan permohonan dengan selisih 33 (tiga puluh tiga).

\section{B. Mekanisme Pelaksanaan Pemungutan Suara Ulang di TPS.}

\section{Pelaksanaan PSU di TPS}

Untuk dapat dilakukan pemungutan suara ulang di TPS, apabila dari hasil penelitian dan pemeriksaan Panwas Kecamatan terbukti terdapat 1 (satu) atau lebih keadaan sebagaimana yang telah diuraikan di atas. Selanjutnya hasil penelitian dan pemeriksaan Panwas Kecamatan disampaikan kepada PPK paling lambat 2 (dua) hari setelah Pemungutan Suara. PPK menyampaikan hasil penelitian dan pemeriksaan kepada KPU/KIP Kabupaten/Kota untuk memutuskan hasil penelitian dan pemeriksaan Panwas Kecamatan dalam rapat pleno KPU/KIP Kabupaten/Kota. Hasil rapat pleno ditetapkan dalam Keputusan KPU/KIP Kabupaten/Kota. KPU/KIP Kabupaten/Kota menyampaikan Keputusan kepada KPPS melalui PPK dan PPS. KPPS segera melaksanakan Pemungutan Suara ulang di TPS paling lambat 4 (empat) hari setelah hari Pemungutan Suara. KPU/KIP Kabupaten/Kota menyampaikan 
permintaan Saksi kepada Pasangan Calon untuk hadir dan menyaksikan Pemungutan Suara ulang diTPS. ${ }^{6}$

PSU dapat dilaksanakan pada hari kerja atau hari libur dengan cara KPPS menyampaikan formulir C6.Ulang-KWK kepada Pemilih yang terdaftar dalam DPT, DPPh, dan yang tercatat dalam DPTb paling lambat 1 (satu) hari sebelum Pemungutan Suara ulang di TPS. Adapun bagi Pemilih yang tidak terdaftar dalam DPT, DPPh, dan DPTb sebelumnya tidak dapat menggunakan hak pilihnya. Selanjutnya KPU/KIP Kabupaten/Kota memberitahukan kepada pimpinan instansi, lembaga, perusahaan atau kepala satuan pendidikan agar memberikan kesempatan kepada Pemilih untuk menggunakan hak pilihnya dalamPemungutan Suara ulang. ${ }^{7}$

Dalam Pemungutan Suara ulang di TPS, tidak dilakukan pemutakhiran data Pemilih. Pemilih yang terdaftar dalam salinan DPT, DPPh, dan DPTb di TPS yang melaksanakan Pemungutan Suara ulang, karena keadaan tertentu tidak dapat menggunakan hak pilihnya di TPS tersebut, dapat menggunakan hak pilihnya di TPS lain yang juga melaksanakan Pemungutan Suara ulang. Keadaan tertentu meliputi: a. menjalankan tugas di tempat lain pada hari Pemungutan Suara; b. menjalani rawat inap di rumah sakit atau puskesmas dan keluarga yang mendampingi; c. menjadi tahanan di rumah tahanan atau lembaga pemasyarakatan; d. tugas belajar; e. pindah domisili; dan f. tertimpa bencana alam. Pemilih tersebut meminta formulir Model A.5-KWK kepada PPS setempat dan melaporkan kepindahannya kepada PPS yang wilayah kerjanya meliputi TPS lain yang juga melaksanakanPemungutan Suara ulang. ${ }^{8}$

${ }^{6}$ Pasal 60 Peraturan Komisi Pemilihan Umum Nomor 8 Tahun 2018 Tentang Pemungutan Dan Penghitungan Suara Pemilihan Gubernur Dan Wakil Gubernur, Bupati Dan Wakil Bupati, Dan/Atau Walikota Dan Wakil Walikota.

${ }^{7}$ Pasal 61 Peraturan Komisi Pemilihan Umum Nomor 8 Tahun 2018 Tentang Pemungutan Dan Penghitungan Suara Pemilihan Gubernur Dan Wakil Gubernur, Bupati Dan Wakil Bupati, Dan/Atau Walikota Dan Wakil Walikota.

${ }^{8}$ Pasal 62 Peraturan Komisi Pemilihan Umum Nomor 8 Tahun 2018 Tentang Pemungutan Dan Penghitungan Suara Pemilihan Gubernur Dan Wakil Gubernur, Bupati Dan Wakil Bupati, Dan/Atau Walikota Dan Wakil Walikota. 
Surat Suara untuk Pemungutan Suara ulang, disediakan sebanyak 2.000 (dua ribu) lembar yang diberi tanda khusus, disimpan di KPU Provinsi/KIP Aceh untuk Pemilihan Gubernur dan Wakil Gubernur dan diKPU/KIP Kabupaten/Kota untuk Pemilihan Bupati danWakil Bupati atau WaliKota dan Wakil WaliKota. Penggunaan Surat Suara untuk Pemungutan Suaraulang sebagaimana dimaksud pada ayat (1) diatur lebihlanjut dengan Keputusan KPU Provinsi/KIP Aceh atauKeputusan KPU/KIP Kabupaten/Kota. ${ }^{9}$

Dalam hal Surat Suara tidak mencukupi untuk melaksanakanPemungutan Suara ulang di TPS, KPU/KIP Kabupaten/Kota menetapkan jumlah kekurangan Surat Suara. Dalam Pemilihan Gubernur dan Wakil Gubernur,KPU/KIP Kabupaten/Kota menyampaikan usulan penambahan jumlah Surat Suara kepada KPU Provinsi/KIP Aceh. Dalam Pemilihan Gubernur dan Wakil Gubernur, KPU Provinsi mencetak dan mendistribusikan penambahan Surat Suara. Dalam Pemilihan Bupati dan Wakil Bupati atau WaliKota dan Wakil Wali Kota, KPU/KIP Kabupaten/Kota mencetak dan mendistribusikan penambahan Surat Suara. ${ }^{10}$

Formulir Model C-KWK berhologram dan Model C1-KWK berhologram yang digunakan dalam Pemungutan Suara ulang dimasukkan ke dalam sampul dalam keadaantersegel dan dimasukkan ke dalam kotak suara. Sampul harus disegel dan dimasukkan ke dalam kotak suara. ${ }^{11}$

Berdasarkan uraian sebagaimana yang dijelaskan di atas mengenai pelaksanaan PSU di TPS masih dapat dijaga netralitas oleh penyelenggara dan pemilih dapat memberikan suaranya secara langsung, umum, bebas dan rahasia (Luber) dan Jujur dan Adil (Jurdil) karena PSU di TPS belum

${ }^{9}$ Pasal 63 Peraturan Komisi Pemilihan Umum Nomor 8 Tahun 2018 Tentang Pemungutan Dan Penghitungan Suara Pemilihan Gubernur Dan Wakil Gubernur, Bupati Dan Wakil Bupati, Dan/Atau Walikota Dan Wakil Walikota.

${ }^{10}$ Pasal 64 Peraturan Komisi Pemilihan Umum Nomor 8 Tahun 2018 Tentang Pemungutan Dan Penghitungan Suara Pemilihan Gubernur Dan Wakil Gubernur, Bupati Dan Wakil Bupati, Dan/Atau Walikota Dan Wakil Walikota.

${ }^{11}$ Pasal 65 Peraturan Komisi Pemilihan Umum Nomor 8 Tahun 2018 Tentang Pemungutan Dan Penghitungan Suara Pemilihan Gubernur Dan Wakil Gubernur, Bupati Dan Wakil Bupati, Dan/Atau Walikota Dan Wakil Walikota. 
dipengaruhi oleh hasil atau informasi perolehan suara sementara dari masingmasing Pasangan calon di tingkat TPS sehingga kemurnian suara pemilih masih terjaga secara independen.

\section{Pelaksanaan PSU Pasca Putusan Mahkamah Konstitusi}

Dalam pelaksanaan Pemungutan Suara ulang pasca Putusan Mahkamah Konstitusi yakni KPU Provinsi/KIP Aceh atau KPU/KIP Kabupaten/Kota: a. menyusun dan menetapkan Keputusan KPU Provinsi/KIP Aceh atau Keputusan KPU/KIP Kabupaten/Kota tentang tahapan, program dan jadwal pelaksanaan Pemungutan Suara ulang, dengan tetap memperhatikan tenggat waktu sebagaimana dimaksud dalam putusan Mahkamah Konstitusi; dan b. merencanakan kebutuhan anggaran untuk pelaksanaan Pemungutan Suara ulang. ${ }^{12}$

Keputusan KPU Provinsi/KIP Aceh atau KeputusanKPU/KIP Kabupaten/Kota, paling kurang menetapkan jadwal: a. pembentukan, pengangkatan kembali atau pendaftaran/seleksi baru, dan pelantikan anggota KPPS, PPS dan PPK untuk melaksanakan Pemungutan Suara ulang di TPS dan rekapitulasi Penghitungan Suara di PPK; b. penyampaian formulir Model C6.Ulang-KWK kepada Pemilih yang terdaftar dalam DPT, DPPh dan yang tercatat dalam DPTb untuk TPS yang bersangkutan; c. pendistribusian Surat Suara dan perlengkapan Pemungutan Suara ulang dan Penghitungan Suara di TPS, formulir rekapitulasi Penghitungan Suara di PPS, PPK, KPU/KIP Kabupaten/Kota, dan di KPU Provinsi/KIP Aceh; d. pelaksanaan hari Pemungutan Suara ulang; e. pelaksanaan rekapitulasi Penghitungan Suara di PPK, KPU/KIP Kabupaten/Kota dan KPUProvinsi/KIP Aceh; dan f. penyampaian laporan pelaksanaan Pemungutan Suara ulang kepada Mahkamah Konstitusidan KPU. Dalam hal KPU Provinsi/KIP Aceh melaksanakanPemungutan Suara ulang. ${ }^{13}$

${ }^{12}$ Pasal 69 Peraturan Komisi Pemilihan Umum Nomor 8 Tahun 2018 Tentang Pemungutan Dan Penghitungan Suara Pemilihan Gubernur Dan Wakil Gubernur, Bupati Dan Wakil Bupati, Dan/Atau Walikota Dan Wakil Walikota.

${ }^{13}$ Ibid 
KPU Provinsi/KIP Aceh menyampaikan keputusan kepada: a. KPU; b. Mahkamah Konstitusi; c. Bawaslu Provinsi; dan/atau d. Panwas Kabupaten/Kota. Dalam hal KPU/KIP Kabupaten/Kota melaksanakan Pemungutan Suara ulang, KPU/KIP Kabupaten/Kota menyampaikan keputusan kepada: a. KPU; b. KPU Provinsi/KIP Aceh; c. Mahkamah Konstitusi; d. Bawaslu Provinsi; dan/atau e. Panwas Kabupaten/Kota. KPU Provinsi/KIP Aceh dan KPU/KIP Kabupaten/Kota dalam menyampaikan keputusan kepada KPU dilampiri dengan putusan Mahkamah Konstitusi yang memerintahkan kepada KPU Provinsi/KIP Aceh atau KPU/KIP Kabupaten/Kota untuk melaksanakan Pemungutan Suara ulang di TPS. ${ }^{14}$

Pemungutan Suara ulang di TPS dilaksanakan pada hari kerja atau hari libur. KPU Provinsi/KIP Aceh dan KPU/KIP Kabupaten/Kota memberitahukan kepada pimpinan instansi, lembaga, perusahaan, atau kepala satuan pendidikan agar memberikan kesempatan kepada Pemilih untuk menggunakan hak pilihnya dalam Pemungutan Suara ulang. KPU Provinsi/KIP Aceh dan KPU/KIP Kabupaten/Kota menyampaikan permintaan Saksi kepada Pasangan Calon untuk hadir dan menyaksikan Pemungutan Suara ulang pasca putusan Mahkamah Konstitusi di KPU Provinsi/KIP Aceh dan KPU/KIP Kabupaten/Kota. KPPS menyampaikan formulir Model C6.Ulang-KWK kepada pemilih yang terdaftar dalam DPT, DPPh, danDPTb paling lambat 1 (satu) hari sebelum Pemungutan Suara ulang di TPS. Dalam pelaksanaan Pemungutan Suara ulang di TPS pasca putusan Mahkamah Konstitusi, tidak dilakukan kampanye. ${ }^{15}$

Formulir Model C-KWK berhologram dan Model C1-KWK berhologram yang digunakan dalam Pemungutan Suara ulang pasca putusan Mahkamah Konstitusi di masukkan ke dalam kotak suara. Pada bagian luar

\footnotetext{
${ }^{14}$ Ibid

${ }^{15}$ Pasal 70 dan Pasal 71 Peraturan Komisi Pemilihan Umum Nomor 8 Tahun 2018 Tentang Pemungutan Dan Penghitungan Suara Pemilihan Gubernur Dan Wakil Gubernur, Bupati Dan Wakil Bupati, Dan/Atau Walikota Dan Wakil Walikota.
} 
kotak suara, ditempel label dengan tulisan "PemungutanSuara Ulang Pasca Putusan Mahkamah Konstitusi” dan disegel. ${ }^{16}$

Atas dasar penjelasan sebagaimana yang diuraikan di atas maka PSU Pasca Putusan Mahkamah Konstitusi seperti buah "simalakama”. Bagaimana tidak dilematis karena perolehan masing-masing pasangan calon telah diketahui secara terbuka meskipun suara di TPS-TPS yang dilakukan PSU tidak dihitung (di”0" kan). Namun demikian, jika selisih perolehan suara pasangan calon pemenang dengan suara pasangan calon terbanyak kedua sedikit maka trasaksi jual beli suara di TPS-TPS yang di PSU kan sangat mungkin terjadi sehingga prinsip pemilihan yang luber dan jurdil sangat sulit ditegakkan meskipun dilakukan pengawasan dengan sungguh-sungguh.

\section{PENUTUP}

\section{A. Kesimpulan}

1. untuk dapat dilakukan pemungutan suara ulang dalam pemilihan kepala daerah harus memenuhi alasan-alasan hukum yaitu; adanya ganguan keamanan, pembukaan kotak suara tidak sesuai aturan, pemilih memberi tanda khusus pada surat suara, Petugas KPPS merusak lebih dari I (satu) surat suara, adanya lebih dari 1 (satu) orang yang menggunakan hak pilih lebih dari sekali dan adanya lebih dari 1 (satu) pemilih yang tidak terdaftar menggunakan hak pilih. Hal tersebut yang telah dibuktikan melalui proses pemeriksaan yang dilakukan oleh Pengawas dimasing-masing jenjang yang kemudian dikeluarkan rekomendasi untuk dilakukan Pemungutan suara Ulang.

2. alasan-alasan pemungutan suara ulang yang telah dibuktikan melalui proses pemeriksaan yang dilakukan oleh Pengawas dikuatkan dengan adanya rekomendasi terhadap TPS-TPS untuk dilakukan Pemungutan Suara Ulang dengan mekanisme Pemungutan Suara Ulang dilakukan di TPS-TPS tersebut

${ }^{16}$ Pasal 72 Peraturan Komisi Pemilihan Umum Nomor 8 Tahun 2018 Tentang Pemungutan Dan Penghitungan Suara Pemilihan Gubernur Dan Wakil Gubernur, Bupati Dan Wakil Bupati, Dan/Atau Walikota Dan Wakil Walikota. 
oleh KPUD dan Panwasluh dengan supervisi dan kordinasi dilakukan oleh lembaga penyelenggara pada tingkat di atasnya ditingkat yang terbukti adanya pelanggaran dengan memenuhi alasan PSU.

\section{B. Saran}

1. alasan-alasan hukum untuk dapat dilakukan pemungutan suara ulang di TPSTPS yang terbukti adanya pelanggaran hukum seharusnya dapat diselesaikan pada tingkat proses bukan melalui sebuah putusan pada tingkat perselisihan hasil di Mahkamah Konstitusi.

2. mekanisme pelaksanaan PSU pasca Putusan Mahkamah Konstitusi sangat dilematis bagi penyelenggara pemilihan dalam menegakkan prinsip pemilihan yang jurdil dan adil karena sangat sulit bagi pengguna hak pilih memberikan hak pilihnya secara obyektif karena sangat dipengaruhi banyak aspek seperti telah diketahuinya hasil perolehan suara dari paslon yang bersaingsehingga penggunaan hak pilih menjadi sabgat transaksional.

\section{DAFTAR PUSTAKA}

\section{Buku:}

Heru Widodo, "Penyelesaian Sengketa Hasil Pemilukada: Evaluasi terhadap Prosedur Beracara di Mahkamah Konstitusi Indonesia Tahun 2008-2014, Disertasi Program Doktor Ilmu Hukum Universitas Pedjadjaran Bandung, 2017.

Mahfud MD, "Evaluasi Pemilukada dalam Prespektif Demokrasi dan Hukum”, dalam Demokrasi Lokal, Evaluasi Pemilukada di Indonesia, Jakarta: Konstitusi Pers, 2012.

Suharizal, Pemilukada: Regulasi, Dinamika dan Konsep Mendatang, Jakarta: Raja Grafindo, 2011.

Janedjri M. Gaffar, Materi Bimtek "Sosialisasi Pemahaman Hak Konstitusional Warga Negara bagi Asosiasi Dosen Pendidikan Pancasila dan Kewarganegaraan, dan Asosiasi Pengajar Hukum Acara Mahkamah Konstitusi DKI Jakarta”, Jakarta, 12 November 2015. 


\section{Undang-Undang:}

Undang-undang No. 10 Tahun 2016 Tentang Perubahan Kedua Atas Undang-Undang Nomor 1 Tahun 2015 Tentang Penetapan Peraturan Pemerintah Pengganti Undang-Undang Nomor 1 Tahun 2014 Tentang Pemilihan Gubernur, Bupati, Dan Walikota Menjadi Undang-Undang.

\section{Putusan Mahkamah Konstitusi :}

Putusan Mahkamah Konstitusi No. 120/PHP.BUP-XIV/2016 tanggal 4 Januari 2016 tentang Pemilihan Kepala Daera Kabupaten Muna Sulawesi Tenggara.

Putusan Mahkamah Konstitusi No. 102/PUU-VII/2009 tentang Pengujian UU No 42 Tahun 2008 tentang Pemilihan Presiden dan Wakil Presiden.

Putusan Mahkamah Konstitusi No. 28/PHPU.D-VIII/2010 tentang Perselisihan Hasil Pemilukada Gresik.

Putusan Mahkamah Konstitusi No 209-210/PHPU.D-VIII/2010 tentang Perselisihan Hasil Pemilukada Tangerang Selatan

Putusan Mahkamah Konstitusi No 77/PHPU.D-VIII/2012 tentang Perselisihan Hasil Pemilukada Brebes.

Peraturan Komisi Pemilihan Umum Nomor 8 Tahun 2018 Tentang Pemungutan Dan Penghitungan Suara Pemilihan Gubernur Dan Wakil Gubernur, Bupati Dan Wakil Bupati, Dan/Atau Walikota Dan Wakil Walikota.

\section{Internet:}

http://bawaslu.go.id/id/berita/psu-jilid-ii-pilkada-kabupaten-muna-digelar 